\title{
Identifikasi Mangga Harum Manis Karbitan dan Tidak Karbitan Dengan Learning Vector Quantization
}

\section{Identification Carbide and Non Carbide Harum Manis Mango Using Learning Vector Quantization}

\author{
Wahyu Puspitaningrum ${ }^{1}$, Supatman² \\ ${ }^{1,2}$ Program Studi Teknik Informatika, Fakultas Teknologi Informasi, Universitas Mercu Buana Yogyakarta, \\ Jl. Wates Km. 10 Yogyakarta 55753, Indonesia \\ Email: wahyupuspitaningrum@gmail.com ${ }^{1}$, supatman@mercubuana-yogya.ac.id ${ }^{2}$
}

\begin{abstract}
ABSTRAK
Buah mangga memiliki banyak jenis salah satunya adalah mangga harum manis. Kematangan buah mangga arum manis ada yang alamiah atau melalui proses pengkarbitan. Karbit adalah kepanjangan dari kalsium karbida. Karbit biasanya digunakan dalam proses las karbit dan juga dapat mempercepat pematangan buah. Pengambilan sample dilakukan pada dua jenis kematangan mangga harum manis yaitu mangga harum manis karbitan dan tidak karbitan. Pengembangan algoritma yang dilakukan bertujuan untuk mengidentifikasi mangga harum manis yang dapat membedakan kematangan mangga karbitan dan tidak karbitan menggunakan Learning Vector Quantization (LVQ). Ciri yang digunakan untuk mengidentifikasi citra mangga adalah rata-rata, varian dan standar deviasi. Jumlah data pelatihan yang digunakan terdiri dari 2 kelas (kelas 1: mangga karbitan, kelas 2: mangga tidak karbitan), dan masing-masing kelas berjumlah 30 data pelatihan dengan total data berjumlah 60 data pelatihan. Sedangkan untuk data uji masing-masing kelas menggunakan 25 data uji dengan total berjumlah 50 data uji. Pada proses pelatihan menggunakan parameter LVQ (alfa 0.001 dengan dec alfa 0.9) diperoleh unjukkerja terbaik sebesar 98.33\%. Bobot akhir yang diperoleh dari unjukkerja terbaik pada pelatihan digunakan untuk melakukan pengenalan. Unjuk kerja terbaik dari 50 data uji mencapai $98 \%$ dengan perincian $96 \%$ mangga karbitan dan $100 \%$ mangga tidak karbitan.
\end{abstract}

Kata Kunci: Histogram, Mangga Harum Manis, Neural Network, Learning Vector Quantization.

\begin{abstract}
There are many types of mango, one of which is harum manis mango. The maturity of sweet arum mango is natural or through the carbonylation process. Carbide is an extension of calcium carbide. Carbide is usually used in the carbide welding process and can also speed up fruit ripening. Sampling was carried out on two types of maturity of harum manis mango, which are sweet and sweet carbitan mango and not carbitan. The development of the algorithm aimed to identify sweet fragrant mangoes that can distinguish the maturity of carbitan and non-carbite mangoes using the Learning Vector Quantization (LVQ). The characteristics used to identify the image of a mango are average, variance and standard deviation. The amount of training data used consisted of 2 classes (class 1: carbitan mangoes, class 2: non-carbite mangoes), and each class consisted of 30 training data with a total of 60 training data. While for the test data each class uses 25 test data with a total of 50 test data. In the training process using LVQ parameters (alpha 0.001 with dec alpha 0.9) obtained the best performance of $98.33 \%$. The final weight obtained from the best performance at the training was used to identify the data for testing. The best performance of 50 test data reached $98 \%$ with details of $96 \%$ carbitan mangoes and 100\% non-carbite mangoes
\end{abstract}

Keywords: Harum Manis Mango, Learning Vector Quantization (LVQ), Histogram

\section{PENDAHULUAN}

Buah adalah makanan yang tidak dapat terpisahkan dari masyarakat, salah satu buah yang gemar dikonsumsi masyarakat Indonesia adalah buah mangga. 
Mangga atau mempelam adalah nama sejenis buah. Mangga termasuk ke dalam marga Mangifera, yang terdiri dari 35-40 anggota dan suku Anacardiaceae. Nama ilmiahnya adalah Mangifera indica. Nama ini kira-kira mengandung arti: "(pohon) yang berbuah mangga, berasal dari India”.

Mangga memiliki kandungan vitamin $\mathrm{C}$, vitamin A, karbohidrat, betakaroten dan serat. Selain rasanya yang lezat, mengkonsumsi buah mangga sangat bermanfaat untuk kesehatan dan dapat terhindar dari beberapa penyakit diantaranya mengurangi kadar kolesterol, pencegah kangker, membakar kalori, menyehatkan kulit wajah, meningkatkan kekebalan tubuh, menyehatkan mata, menjaga kesehatan gigi, gusi dan baik untuk pencernaan.

Karbit adalah kepanjangan dari kalsium karbida yaitu sebuah senyawa kimia dengan rumus kimia $\mathrm{CaC} 2$. Senyawa murninya tidak berwarna, tetapi kalsium karbida yang biasanya digunakan warnanya adalah abu-abu atau coklat dengan kandungan $\mathrm{CaC} 2$ hanya sekitar 80-85\% (sisanya adalah $\mathrm{CaO}, \mathrm{Ca} 3 \mathrm{P} 2, \mathrm{CaS}, \mathrm{Ca} 3 \mathrm{~N} 2$, dan $\mathrm{SiC})$. Selain itu, karena adanya kandungan PH3, $\mathrm{NH} 3$, and H2S, maka senyawa ini juga berbau menyengat. Penggunaan utamanya dalam industri adalah untuk pembuatan asetilena dan kalsium sianamida. Karbit biasanya digunakan dalam proses las karbit dan juga dapat mempercepat pematangan buah.

Idealnya buah itu matang di pohon. Namun dengan proses pengarbitan ini, buah yang belum matang akan cepat matang dalam waktu sekitar 2x24 jam. Namun, gas dari karbit ini dapat menempel di kulit dan diserap ke dalam daging buah. Jika tertelan tentu akan menimbulkan dampak berbahaya.

Banyak masyarakat yang kesulitan memilih manakah mangga yang karbitan dan yang tidak karbitan, sedangkan warna dan bentuknya hampir sama, maka diangkatlah topik identifikasi buah mangga harum manis karbitan dan tidak karbitan dengan Neural Network. Dengan algoritma ini nantinya dapat mengidentifikasi mangga harum manis karbitan dan tidak karbitan sehingga kekeliruan pembelian buah mangga harum manis oleh konsumen dapat dikurangi.

\section{TINJAUAN PUSTAKA}

Dalam penelitian yang berjudul "Klasifikasi Mutu Jeruk Nipis dengan Metode Learning Vektor Quantization (LVQ)", proses untuk mendapatkan citra jeruk nipis adalah proses capture melalui webcam. Data hasil capture webcam proses pelatihan ataupun pengujian sistem, terlebih dahulu melalui preprocessing dan ekstraksi ciri. Adapun preprocessing yang akan dilalui adalah proses resize dan ekstraksi ciri. Proses pelatihan LVQ akan menghasilkan bobot yang kemudian akan digunakan untuk proses pengujian. Pengujian yang dilakukan menggunakan 20 sampel jeruk nipis terdiri dari 5 jeruk nipis muda, 5 jeruk nipis setengah matang, 5 jeruk nipis matang dan 5 jeruk nipis busuk. Tiap jeruk nipis dilakukan 10 kali pengujian yang menghasilkan akurasi sistem secara keseluruhan $76 \%$ dan error $24 \%$ dengan rincian $82 \%$ untuk jeruk nipis muda, $76 \%$ untuk jeruk nipis setengah matang, $80 \%$ untuk jeruk nipis matang dan $66 \%$ untuk jeruk nipis busuk (Romadhon \& Widyaningrum (2015).

Dalam penelitian yang berjudul "Pengenalan Wajah Menggunakan Learning Vector Quantization (LVQ)". Proses pengenalan wajah dibagi menjadi tiga bagian utama, yaitu proses awal (prepocessing), proses pelatihan (learning) dan selanjutnya digunakan untuk proses identifikasi wajah. Dengan menggunakan kecerdasan buatan Learning Vector Quantization (LVQ), hasil deteksi wajah, dari 35 data citra wajah input, yang digunakan untuk learning sebanyak 25 data citra wajah dan data 35 data citra wajah digunakan untuk mapping atau pengujian dan yang berhasil diidentifikasi ada 30 data citra ( 88,2\%) (Heranurweni, 2010).

Dalam penelitian yang berjudul "Identifikasi Gula Jawa Asli Dengan Gula Jawa Campuran Menggunakan Metode Learning Vector Quantization". Penelitian ini bertujuan mengembangkan algoritma yang dapat mengidentifikasi gula jawa asli dan gula jawa campuran menggunakan metode Learning Vector Quantization (LVQ). Properti citra yang digunakan adalah warna dengan ciri rata-rata, varian dan standar deviasi. Jumlah data pelatihan yang digunakan terdiri dari 2 kelas, dan masingmasing kelas berjumlah 30 data pelatihan dengan total data berjumlah 60 data. Sedangkan untuk data uji masing-masing kelas menggunakan 20 data uji dengan total berjumlah 40 data uji. Unjuk kerja pelatihan LVQ terbaik adalah 98,33\%, pada alfa 0,001 dengan dec alfa 0,9 . Sedangkan unjuk kerja terbaik identifikasi dengan 40 data uji adalah 95\% (Nanda, 2018).

\section{METODOLOGI PENELITIAN}


Jalannya sistem dalam proses penelitian ditunjukkan pada Gambar 1.

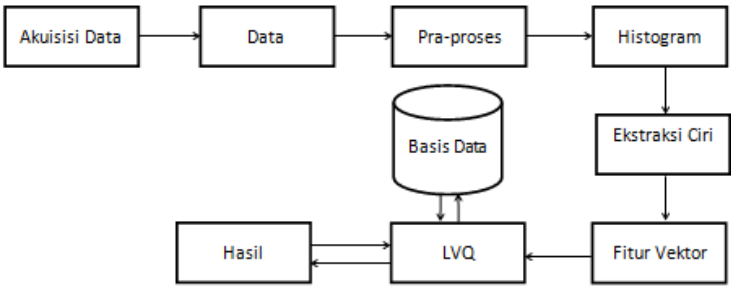

Gambar 1. Jalan Penelitian

\subsection{Akuisisi data}

Pengambilan gambar menggunakan kamera smartphone VIVO Y65 dengan kamera 13 mega piksel dan jarak $25 \mathrm{~cm}$ vertikal di atas. Data citra mangga harum manis yang diambil memiliki pencahayaan yang normal dan jarak pengambilan yang sama.

\subsection{Data}

Tahap akuisisi data yang dilakukan akan menghasilkan sebuah data yang berupa citra buah mangga harum manis karbitan dan tidak karbitan. Citra mangga harum manis ini yang digunakan pada pemrosesan tahap berikutnya.

\subsection{Pra-proses}

Tahapan pra proses ini meliputi cropping dan grayscale. Cropping merupakan teknik pemotongan gambar yang digunakan untuk menentukan secara tepat bagian yang ingin diolah.. Pada proses cropping dilakukan dengan memotong ukuran citra menjadi 500x500 piksel.

Proses selanjutnya adalah dengan mengubah citra dari tiga layer menjadi satu layer gray. Proses dari grayscale ditunjukkan pada Gambar 2.

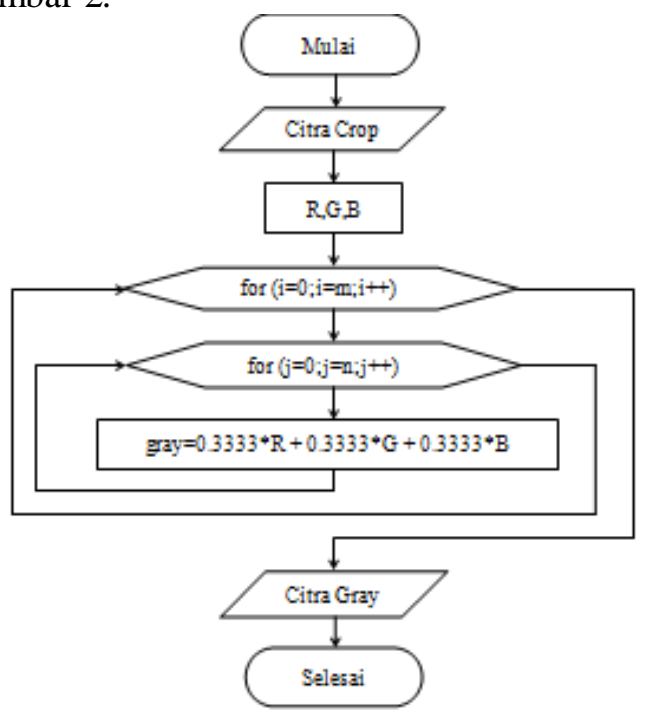

Gambar 2. Diagram Alir Proses Grayscale
Keterangan :

Citra Crop

: citra yang didapat dari proses crop

Layer RGB : layer merah, hijau dan biru dari citra $c r o p$

m : banyaknya piksel baris dari citra crop

n : banyaknya piksel kolom dari citra crop

citra gray $\quad$ : citra yang dihasilkan dari proses gray

\subsection{Histogram}

Citra yang sudah menjadi grayscale diproses untuk menentukan komposisi warna RGB yang digambarkan ke dalam grafik derajat keabuan (gray level). Histogram warna merepresentasikan distribusi jumlah piksel untuk tiap intensitas warna dalam citra. Diagram alir dari histogram citra ditunjukkan pada Gambar 3.

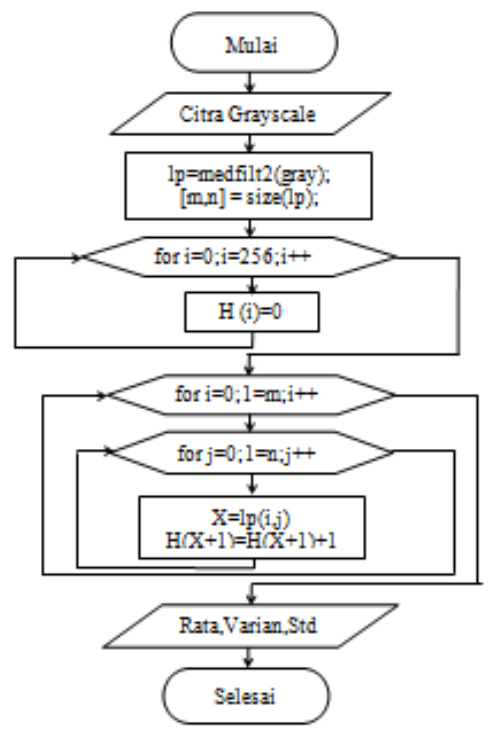

Gambar 3. Diagram Alir Histogram Citra

Keterangan :

Citra grayscale : citra yang didapat dari proses grayscale

$\mathrm{m}$

: banyaknya piksel baris pada citra

n : banyaknya piksel kolom pada citra

\subsection{Ekstraksi Ciri}

Ekstraksi ciri merupakan suatu pengambilan ciri / feature dari suatu obyek, kemudian digunakan sebagai parameter untuk membedakan antara obyek satu dengan yang lainnya pada tahapan identidikasi citra. Proses ini berkaitan dengan kuantisasi karakteristik citra ke dalam sekelompok nilai ciri yang sesuai. Sehingga mendapatkan informasi kuantitatif dari ciri yang dapat membedakan kelas-kelas suatu 
obyek. Dalam penelitian ini menggunakan 3 ciri yaitu rata-rata, varian, dan standar deviasi (std).

Rata-rata (mean) adalah suatu bilangan yang mewakili sekumpulan data. Nilai rata-rata dapat ditentukan dengan membagi jumlah data dengan banyaknya data. Rumus untuk mencari rata-rata seperti pada Persamaan 1.

$\mu=\frac{\sum_{\mathrm{i}=1}^{\mathrm{N}} \mathrm{X} 1}{\mathrm{~N}}$

Keterangan :

$\mu \quad=$ rata-rata

$\mathrm{N}$ = banyaknya data

$\mathrm{X}=$ jumlah data

Varian adalah ukuran seberapa tersebarnya data. Varian yang rendah menandakan data yang berkelompok dekat satu sama lain. Varian yang tinggi menandakan data yang lebih tersebar. Rumus untuk mencari varian seperti pada Persamaan 2.

$S^{2}=\frac{\sum_{i=1}^{n}(X i-\bar{X})^{2}}{n-1}$

Keterangan :

$\mathrm{S}^{2} \quad$ : varian

$\mathrm{Xi} \quad$ : nilai $\mathrm{x}$ ke-i

$\overline{\mathrm{X}} \quad$ : rata-rata (mean)

$\mathrm{n} \quad$ : jumlah data

Standar deviasi adalah nilai statistik yang digunakan untuk menentukan bagaimana sebaran data dalam sampel, dan seberapa dekat titik data ke mean atau rata-rata dari nilai sampel. Rumus mencari varian seperti pada Persamaan 3.

$$
\sigma=\sqrt{\frac{\sum_{i=1}^{\mathrm{n}}(\mathrm{X} 1-\overline{\mathrm{X}})^{2}}{\mathrm{n}-1}}
$$

Keterangan :

$\sigma \quad:$ standar deviasi

$\mathrm{Xi}$ : nilai $\mathrm{X} \mathrm{ke-1}$

$\overline{\mathrm{X}} \quad$ : rata-rata (mean)

$\mathrm{N} \quad$ : jumlah data

\subsection{Fitur Vektor}

Setelah melakukan ekstraksi ciri dari citra mangga harum manis maka akan diperoleh sebuah ciri dalam bentuk vektor. Ciri tersebut kemudian disimpan dalam database yang digunakan sebagai acuan untuk proses pelatihan. Dari proses pelatihan akan diperoleh bobot akhir. Pengenalan data uji dilakukan dengan membandingkan bobot akhir dengan ciri data uji, kemudian mencari jarak terdekat untuk menentukan kelasnya.

\subsection{Identifikasi Menggunkan Learning Vector Wuantization \\ Learning Vektor Quantization adalah} sebuah metode klasifikasi dimana setiap unit output mempresentasikan sebuah kelas. Learning Vektor Quantization digunakan untuk pengelompokan, dimana jumlah kelompok sudah ditentukan target dan kelasnya. Kelas-kelas yang didapatkan dari sebagai hasil dari lapisan kompetitif ini tergantung pada jarak antara vektorvektor input. Jika dua vektor input mendekati sama, maka lapisan kompetitif akan meletakkan kedua vektor input tersebut ke dalam kelas yang sama. Sehingga dapat melakukan proses identifikasi mangga harum manis karbitan dan tidak karbitan.

Proses Learning Vektor Quantization dapat dilihat pada Gambar 4.

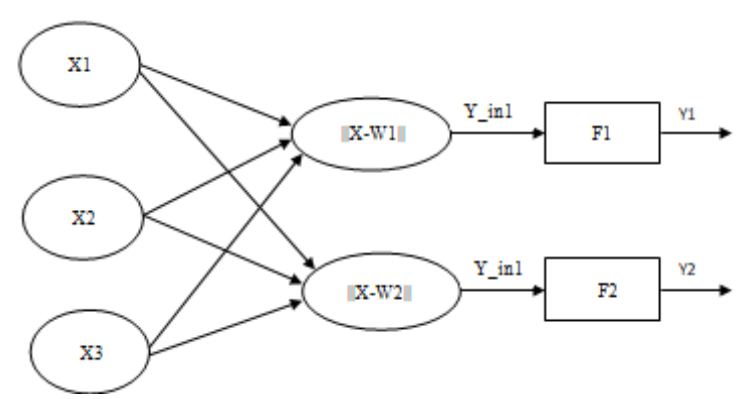

Gambar 4. Arsitektur Jaringan LVQ

Keterangan :

$\mathrm{X} 1 \ldots \mathrm{n}=$ Vektor masukan.

$\mathrm{F} \quad=$ Lapisan kompetitif.

Y_in = Masukan ke lapisan kompetitif.

$\mathrm{Y} \quad=$ Keluaran.

$\mathrm{W}=$ Vektor bobot untuk unit

keluaran.

$\| \mathrm{X}-\mathrm{W} 1 \ldots \mathrm{n}=$ Selisih nilai jarak Euklidean antara vektor input.

Sesuai dengan Gambar 4 lapisan masukan disimbolkan dengan nilai X1, X2, X3. Jaringan LVQ diatas memiliki 2 kelas yang berbeda, yaitu mangga karbitan dan mangga tidak karbitan.

Berikut adalah diagram alir Learning Vektor Quantization yang ditunjukkan pada Gambar5. 


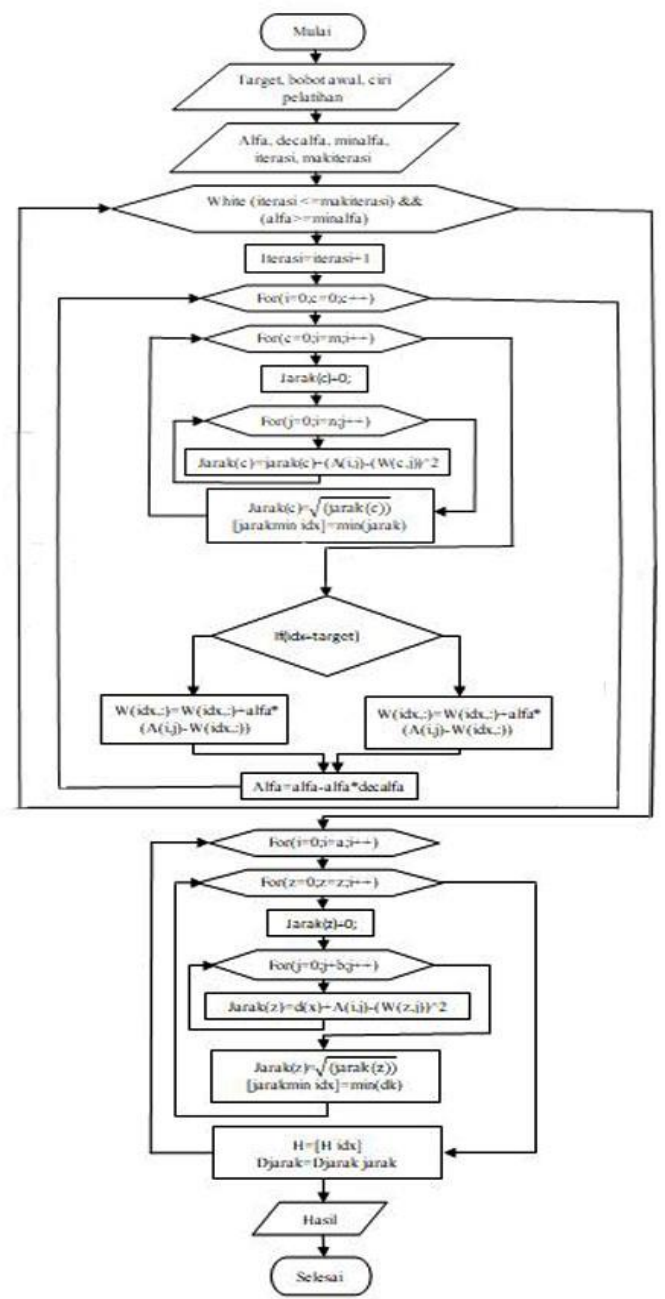

Gambar 5. Diagram Alir Metode Learning Vektor Quantization (LVQ)

Keterangan :

W(lama) : bobot awal

W(baru) : bobot akhir

m,n : baris dan kolom matriks data pelatihan

o,p : baris dan kolom matriks bobot awal

a,b : baris dan kolom matriks data pengujian

idx $\quad$ : jarak terdekat

\section{PEMBAHASAN}

\subsection{Akuisisi Data Citra}

Hasil pengambilan citra menggunakan smartphone ditunjukkan pada Gambar 4.1.

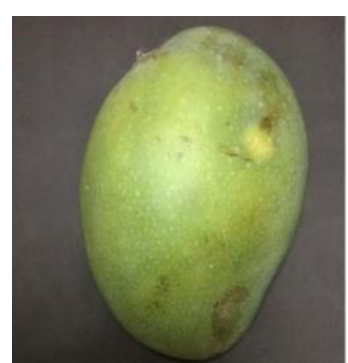

(A)

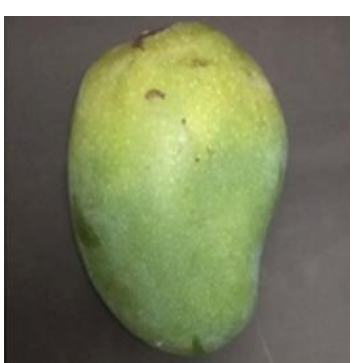

(B)
Gambar 6. Citra (A) Mangga Karbitan dan Citra (B) Mangga Tidak Karbitan

\subsection{Pra-proses}

Gambar 7.

Hasil proses cropping ditunjukkan pada

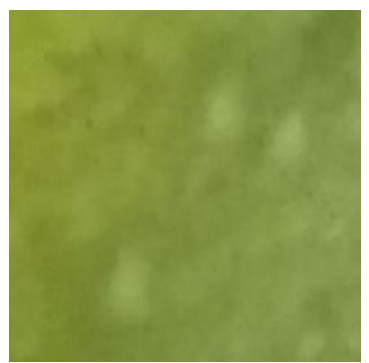

(A)

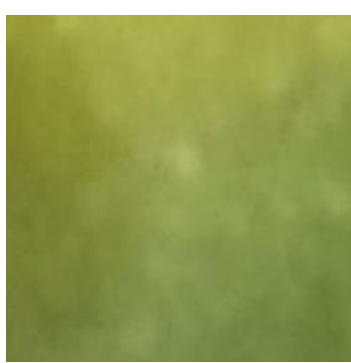

(B)
Gambar 7. Citra Hasil Cropping (A) Mangga Karbitan dan (B) Mangga Tidak Karbitan Gambar 8.

Hasil proses gray yang ditunjukkan pada

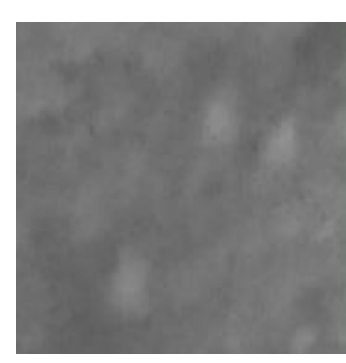

(A)

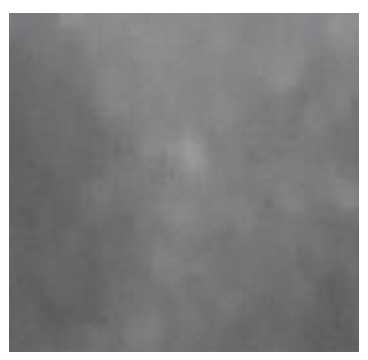

(B)
Gambar 8. Citra Hasil Grayscale (A) Mangga Karbitan dan (B) Mangga Tidak Karbitan

\subsection{Histogram}

Proses selanjutnya yaitu mengolah data citra menjadi histogram. Setelah melalui tahap pra-proses data citra kemudian dicari derajat keabuannya. Citra masukan mempunyai 256 derajat keabuan yang nilainya $0-255$. Derajat keabuan yang dimiliki citra mangga akan ditunjukkan dalam grafik. Data citra setelah dilakukan proses histogram ditunjukkan pada Gambar 9. 


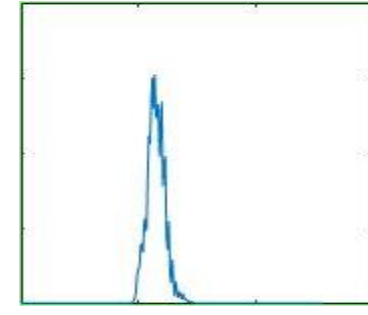

(A)

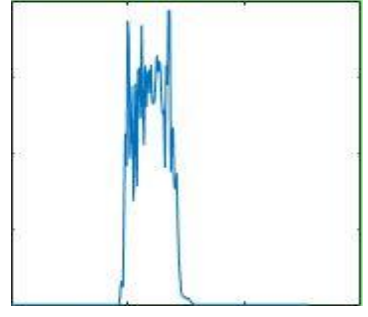

(B)
Gambar 9. Histogram Citra (A) Mangga Karbitan dan (B) Mangga Tidak Karbitan

\subsection{Ekstraksi Ciri}

Data citra mangga yang telah diproses menggunakan histogram kemudian dilakukan ekstraksi ciri menggunakan rata-rata (mean), standar deviasi $(s t d)$ dan varian.

\subsection{Learning Vektor Quantization}

Proses pelatihan pada jaringan syaraf tiruan Learning Vector Quantization (LVQ) menggunakan parameter untuk mengetahui presentase keberhasilan tertinggi. Pelatihan dilakukan utuk mencari bobot akhir yang digunakan dalam proses pengujian. Parameter Learning Vector Quantization (LVQ) dalam pelatihan ditunjukkan pada Tabel 1.

Tabel 1. Parameter LVQ

\begin{tabular}{|l|l|}
\hline \multicolumn{1}{|c|}{ Parameter } & \multicolumn{1}{c|}{ Nilai } \\
\hline Jumlah Data Pelatihan & 60 \\
\hline Jumlah Data Uji & 50 \\
\hline Jumlah Pola Target & 2 \\
\hline Variasi Laju Pelatihan $(\alpha)$ & 0,$1 ; 0,001 ; 0,001$ \\
\hline Update Laju Pelatihan & $\alpha=\alpha-\alpha(\operatorname{dec} \alpha)$ \\
\hline $\begin{array}{l}\text { Variasi Penurunan Laju } \\
\text { Pelatihan }(\text { dec } \alpha)\end{array}$ & $\begin{array}{l}0,1 ; 0,2 ; 0,3 ; 0,4 ; 0,5 ; 0, \\
6 ; 0,7 ; 0,8 ; 0,9\end{array}$ \\
\hline $\begin{array}{l}\text { Minimum Laju Pelatihan yang } \\
\text { Diharapkan }\end{array}$ & 0.000001 \\
\hline Maksimum Iterasi & 1000 \\
\hline
\end{tabular}

Pada penelitian ini seluruh data citra sebanyak 60 data. Untuk data yang digunakan sebagai bobot awal adalah data yang mewakili kelas (target), data tersebut diambil secara acak pada asing-masingkelas pada data yang ada. Bobot awal yang digunakan dalam penelitian ini ditunjukkan pada Tabel 2.

Tabel 2. Bobot Awal

\begin{tabular}{|c|c|c|c|c|}
\hline No & $\begin{array}{c}\text { Kode } \\
\text { Citra }\end{array}$ & Rata-rata & Varian & $\begin{array}{c}\text { Standar } \\
\text { Deviasi }\end{array}$ \\
\hline 1 & K01 & 175,45449 & 1012,0617 & 100,60128 \\
\hline 2 & T01 & 160,2790 & 8947,9995 & 94,5938 \\
\hline
\end{tabular}

Tabel 2 menunjukkan bobot yang pertama untuk kelas 1 yaitu mangga karbitan dan kelas 2 yaitu mangga tidak karbitan.

Database digunakan sebagai data pelatihan dengan menentukan target dan bobot awal. Target dibagi menjadi 2 kelas yaitu masing-masing kelas ada 30 data dengan total 60 data pelatihan. Bobot awal diambil pada salah satu data masing-masing kelas dari data hasil ekstraksi ciri yang sudah dibuat. Dalam menentukan hasil kinerja identifikasi citra mangga dilakukan dengan mengubah parameter laju pelatihan awal (alfa) dan penurunan laju pelatihan (decalfa).

Kinerja dari pelatihan identifikasi mangga harum manis karbitan dan tidak karbitan menggunakan metode Learning Vector Quantization (LVQ) seperti yang ditunjukkan pada Tabel 3.

Tabel 3. Unjuk Kerja Pelatihan Identifikasi Mangga Karbitan dan Tidak Karbitan

\begin{tabular}{|c|c|c|c|c|}
\hline No & $\begin{array}{l}\text { Dec } \\
\text { Alfa }\end{array}$ & Alfa & Iterasi & Komulatif(\%) \\
\hline 1 & \multirow{3}{*}{0.1} & 0.1 & 110 & 50 \\
\hline 2 & & 0.01 & 88 & 50 \\
\hline 3 & & 0.001 & 66 & 96.666 \\
\hline 4 & \multirow{3}{*}{0.2} & 0.1 & 52 & 50 \\
\hline 5 & & 0.01 & 42 & 53.333 \\
\hline 6 & & 0.001 & 31 & 93.333 \\
\hline 7 & \multirow{3}{*}{0.3} & 0.1 & 33 & 50 \\
\hline 8 & & 0.01 & 26 & 58.333 \\
\hline 9 & & 0.001 & 20 & 96.666 \\
\hline 10 & \multirow{3}{*}{0.4} & 0.1 & 23 & 50 \\
\hline 11 & & 0.01 & 19 & 66.666 \\
\hline 12 & & 0.001 & 14 & 98.333 \\
\hline 13 & \multirow{3}{*}{0.5} & 0.1 & 17 & 50 \\
\hline 14 & & 0.01 & 14 & 80 \\
\hline 15 & & 0.001 & 10 & 98.333 \\
\hline 16 & \multirow{3}{*}{0.6} & 0.1 & 13 & 50 \\
\hline 17 & & 0.01 & 11 & 81.666 \\
\hline 18 & & 0.001 & 8 & 98.333 \\
\hline 19 & \multirow{3}{*}{0.7} & 0.1 & 10 & 50 \\
\hline 20 & & 0.01 & 8 & 86.666 \\
\hline 21 & & 0.001 & 6 & 98.333 \\
\hline 22 & \multirow{3}{*}{0.8} & 0.1 & 8 & 50 \\
\hline 23 & & 0.01 & 6 & 86.666 \\
\hline 24 & & 0.001 & 5 & 98.333 \\
\hline 25 & \multirow{3}{*}{0.9} & 0.1 & 5 & 50 \\
\hline 26 & & 0.01 & 4 & 96.666 \\
\hline 27 & & 0.001 & 3 & 98.333 \\
\hline
\end{tabular}


Tabel 3 menunjukkan hasil unjuk kerja citra pelatihan terdapat persentase tertinggi yaitu 98.33\%. Dari alfa dan decalfa tersebut kemudian meghasilkan bobot akhir yang digunakan untuk pengujian. Pengujian dilakukan dengan mencari jarak terdekat antara bobot akhir dengan data uji untuk menentikan kelasnya.

Pengenalan data pelatihan yag paling baik akan disimpan menjadi bobot akhir dan akan digunakan untuk melakukan pengenalan terhadap data uji. Bobot akhir ditunjukkan pada Tabel 4.

Tabel 4. Bobot Akhir

\begin{tabular}{|c|c|c|c|}
\hline No & Rata-rata & Varian & $\begin{array}{c}\text { Standar } \\
\text { Deviasi }\end{array}$ \\
\hline 1 & 177,5137 & 10470,684 & 100,04118 \\
\hline 2 & 157,6637 & 8666,8873 & 94,0603 \\
\hline
\end{tabular}

Pengenalan dilakukan dengan mencari jarak terdekat antara bobot akhir Pengenalan dilakukan dengan mencari jarak terdekat antara bobot akhir dengan data uji. Pengenalan data uji mangga karbitan dan tidak karbitan ditunjukkan pada Tabel 5.

Tabel 5 Pengenalan Data Uji

\begin{tabular}{|c|c|c|c|c|}
\hline No & Dec Alfa & Alfa & Iterasi & $\begin{array}{c}\text { Komulatif } \\
(\%)\end{array}$ \\
\hline 1 & \multirow{3}{*}{0.1} & 0.1 & 110 & 50 \\
\hline 2 & & 0.01 & 88 & 50 \\
\hline 3 & & 0.001 & 66 & 86 \\
\hline 4 & \multirow{3}{*}{0.2} & 0.1 & 52 & 50 \\
\hline 5 & & 0.01 & 42 & 52 \\
\hline 6 & & 0.001 & 31 & 98 \\
\hline 7 & \multirow{3}{*}{0.3} & 0.1 & 33 & 50 \\
\hline 8 & & 0.01 & 26 & 68 \\
\hline 9 & & 0.001 & 20 & 98 \\
\hline 10 & \multirow{3}{*}{0.4} & 0.1 & 23 & 50 \\
\hline 11 & & 0.01 & 19 & 76 \\
\hline 12 & & 0.001 & 14 & 98 \\
\hline 13 & \multirow{3}{*}{0.5} & 0.1 & 17 & 50 \\
\hline 14 & & 0.01 & 14 & 80 \\
\hline 15 & & 0.001 & 10 & 98 \\
\hline 16 & \multirow{3}{*}{0.6} & 0.1 & 13 & 50 \\
\hline 17 & & 0.01 & 11 & 82 \\
\hline 18 & & 0.001 & 8 & 98 \\
\hline 19 & \multirow{3}{*}{0.7} & 0.1 & 10 & 50 \\
\hline 20 & & 0.01 & 8 & 82 \\
\hline 21 & & 0.001 & 6 & 98 \\
\hline
\end{tabular}

\begin{tabular}{|l|r|r|r|l|}
22 & \multirow{4}{*}{0.8} & 0.1 & 8 & 50 \\
\hline 23 & 0.01 & 6 & 84 \\
\hline 24 & & 0.001 & 5 & 98 \\
\hline 25 & \multirow{4}{*}{0.9} & 0.1 & 5 & 50 \\
\hline 26 & 0.01 & 4 & 84 \\
\hline 27 & & 0.001 & 3 & 98 \\
\hline
\end{tabular}

Berdasarkan Tabel 3 menunjukkan hasil pengujian terbaik yaitu mampu mengidentifikasi buah mangga harum manis yang matang dengan melalui pengkarbitan dan matang alami dengan persentasi identifikasi mencapai $98 \%$.

\section{KESIMPULAN}

Hasil dari penelitian identifikasi mangga harum manis karbitan dan tidak karbitan dapat disimpulkan sebagai berikut:

1. Unjuk kerja terbaik pelatihan dengan 60 data diperoleh akurasi sebesar 98,333\% dengan rincian (mangga karbitan 100\% dan mangga tidak karbitan 96.666\%) pada alfa 0.001 dan dec alfa 0.9 .

2. Unjuk kerja pengujian dengan 50 data diperoleh akurasi sebesar 98\% dengan rincian (mangga karbitan 96\% dan mangga tidak karbitan 100\%).

\section{UCAPAN TERIMA KASIH}

Ucapan terima kasih penulis sampaikan kepada semua rekan-rekan FTI UMB Yogyakarta yang telah membantu dalam penelitian ini.

\section{DAFTAR PUSTAKA}

Chandra, E., N. (2018). Identifikasi Gula Jawa Asli Dengan Gula Jawa Campuran Menggunakan Metode Learning Vector Quantization. Prosiding Seminar Nasional Multimedia \& Artificial Intelligence, ISBN: 978-602-52470-4-0. Hal 126.

Danoedoro, P.(1996). Pengolahan Citra digital Teori dan Aplikasinya dalam Bidang Penginderaan Jauh, Fakultas Geografi Universitas Gadjah Mada.

Fadlil, A., \& Yeki, S. (2010). Sistem Verifikasi Wajah Menggunakan Jaringan Saraf Tir-uan Learning Vektor Quantization. Jurnal Informatika, Vol 4, No. 2, Hal 480-487.

Fadlisyah. (2007). Computer Vision dan Pengolahan Citra. Andi Publisher. 
Jakarta.

Heranurweni, S.(2010). Pengenalan Wajah Menggunakan Learning Vector Quantization (LVQ). Prosiding Seminar Nasional Sains dan Teknologi. Hal 6674

Munir, R.(2004). Pengolahan Citra Digital, Bandung Informatika.

Murni \& Aniati.(1992). Pengantar Pengolahan Citra. Elex Media Komputindo.

Putra, Darma.(2010). Pengolahan Citra digital. Penerbit Andi. Yogyakarta.

Romadhon ,A. S., \& Widyaningrum,T. V.(2015). Klasifikasi Mutu Jeruk Nipis dengan Metode Learning Vektor Quantization (LVQ). Jurnal Ilmiah Rekayasa, Vol 8, No. 2, ISSN: 02169495, Hal 121-128.

Sutoyo, T. (2019). Teori Pengolahan Citra Digital. Penerbit ANDI.
Utomo, P.(2016). Sistem Klasifikasi Jenis Beras Menggunakan Metode Learning Vector Quantization. Jurnal Ilmiah Ilmu-ilmu Teknik, Vol 1 No. 2, ISSN: 2502-7042, Hal 61-67.

Qur'ani, D., Y., \& Rosmalinda, S.(2010). Jaringan syaraf tiruan learning vector quantization untuk aplikasi pengenalan tanda tangan. Jurnal Seminar Nasional Aplikasi Teknologi Informasi : G-6.

Yuliana, U., Whidhiasih, N. R., \& Maimunah. (2016). Identifikasi Rasa Buah Mangga Gedong Gincu Cirebon Berdasarkan Citra Red-Green-Blue Menggunakan Jaringan Syaraf Tiruan. Jurnal Penelitian Ilmu Komputer, System Embedded \& Logic. Hal 61-68. 